\title{
Phenomenology in Japan
}

Edited by

\section{ANTHONY J. STEINBOCK}

Department of Philosophy, Southern Illinois University at Carbondale, USA

Reprinted from Continental Philosophy Review, Volume 31 (3), 1998

Springer-Science+Business Media, B.V. 
A.I.P. Catalogue record for this book is available from the Library of Congress.

ISBN 978-90-481-5118-9 ISBN 978-94-017-2602-3 (eBook)

DOI 10.1007/978-94-017-2602-3

Printed on acid-free paper

All Rights Reserved

C1998 Springer Science+Business Media Dordrecht

Originally published by Kluwer Academic Publishers in 1998

No part of the material protected by this copyright notice may be reproduced or utilized in any form or by any means, electronic or mechanical, including photocopying, recording or by any information storage and retrieval system, without written permission from the copyright owner. 


\section{TABLE OF CONTENTS}

ANTHONY J. Steinbock / Introduction: Phenomenology in Japan

TORU TANI / Inquiry into the I, disclosedness, and self-con-

sciousness: Husserl, Heidegger, Nishida

Tetsuya SaKakibara / The relationship between nature and spirit in Husserl's phenomenology revisited

SHIGETO NUKI / The theory of association after Husserl: "Form/ content" dualism and the phenomenological way out

Junichi Murata / Colors in the life-world

HiRoshi KoJima / On the semantic duplicity of the first person pronoun "I" 
For my Mother, Marie Steinbock

We must now declare that because "dim eyesight" is equal, the "flowers of emptiness" are equal; that because "dim eyesight" is birthless, the "flowers of emptiness" are birthless; and that because all dharmas are real nature, the "flowers of dimness" are real nature. These do not concern themselves with past, present, or future, nor do they have anything to do with the beginning, middle, or end. Because they are not obstructed by arising or perishing, they freely cause arising and perishing to arise and perish. They arise in "emptiness" and perish in "emptiness"; they arise in "dimness" and perish in "dimness"; they arise in "flowers" and perish in "flowers." They do this at all times and in all places.

From Dōgen's Shōbōgenzō/Kūge (trans. Hee-Jin Kim)

I mean now: We normally live in our homeworld, or better, in an environing-world which is a world actually familiar to us (albeit a world which is not familiar in all individual realities), a world actually to be realized for us in intuition. In the mediate horizon are heterogenous humanities and cultures; they belong to them as alien and as heterogenous; but alienness means accessibility in genuine inaccessibility, in the mode of incomprehensibility. 